\section{Planting Depth at Onset of Container Production and Subsequent Root Ball Remediation at Transplanting Affects Pin Oak and Littleleaf Linden}

\author{
J. Roger Harris ${ }^{1}$ \\ Department of Horticulture, Virginia Polytechnic Institute and State \\ University, 301 Saunders Hall, Blacksburg, VA 24061
}

\section{Susan D. Day}

Department of Forest Resources and Environmental Conservation and Department of Horticulture, Virginia Polytechnic Institute and State University, 310 Cheatham Hall, Blacksburg, VA 24061

Additional index words. adventitious roots, girdling roots, root flare, structural roots, suckers

Abstract. Root flares of landscape trees are increasingly found to be much deeper than their forest counterparts, indicating that their root systems have been situated deeper in the soil. Planting deeply in production containers contributes to this phenomenon, yet the consequences of deep planting in production containers or the consequences of any adjustments made to planting depth at the time of transplant on growth in the landscape have not been reported for many species. Container-grown $(11.4 \mathrm{~L})$ liners of Tilia cordata Mill. (littleleaf linden) and Quercus palustris Münchh. (pin oak) were planted in 50-L containers with the first main lateral roots (structural roots) at substrate-surface grade or $10 \mathrm{~cm}$ or $20 \mathrm{~cm}$ below grade (deep planting). Trees were grown in the 50-L containers for two growing seasons and in a simulated landscape for three additional seasons after transplanting with the top of the container substrate at soil level or with some roots and substrate removed such that the original structural roots were just below the soil surface (remediated). Deep planting pin oak, but not littleleaf linden, slowed growth during container production; however, the effect did not persist after transplanting. Remediation of the 20 -cm-deep pin oaks slowed growth during all three post-transplant years. Littleleaf linden remediation slowed growth for the first season after transplanting to a simulated landscape for 10-cm-deep trees and for the first two seasons for 20-cm-deep trees. Evaluation of pin oak root systems 3 years after transplanting revealed vigorous growth of non-deflected adventitious roots that had formed on the trunks of deep trees, and these roots appeared to be developing into main structural roots. No adventitious roots were present on littleleaf linden; instead, deflected roots grew and produced deformed root systems. Deep planting of linden reduced suckering; however, we conclude that remediation of deep-planted littleleaf linden is warranted as a result of potential hazards from trunk-girdling roots. In some species such as pin oak, non-deflected, strong adventitious root systems may assume the role of structural roots and diminish the effect of deflected and circling roots systems formed during container production. Remediation of these trees is likely not as critical as for species without abundant adventitious roots.

Green industry professionals have become concerned with an apparent increase in landscape trees with abnormally deep structural roots (deep structural roots). Structural roots form the basic foundation of a tree's root system on which much of the entire future

Received for publication 24 June 2010. Accepted for publication 17 Sept. 2010

This project was partially supported by a grant to the Morton Arboretum in Lisle, IL, from the Urban and Community Forestry Challenge Grants program directed by the U.S. Department of Agriculture under advisement from the National Urban and Community Forestry Advisory Council. Their support is greatly appreciated.

We thank Velva Groover for assistance with data collection and analysis and with photography.

${ }^{1}$ To whom reprint requests should be addressed; e-mail rharris@vt.edu.
Grabosky, 2004) or root systems in compacted soil (Day et al., 1995) are commonly not waterlogged and therefore not likely to be suffering from chronic low soil oxygen concentrations. In contrast, deep roots of newly planted trees during container production may be exposed to waterlogged conditions because the lower sections of containers, especially short ones, are wetter than the corresponding depth of well-drained field soil (Fonteno, 1996; Spomer, 1980), potentially affecting growth by limiting oxygen diffusion to roots. Deep structural roots may also make trees more prone to the destructive effects of trunk-girdling roots (e.g., loss of stability) (Day and Harris, 2008; Wells et al., 2006). For a review of the causes and consequences of deep structural roots of trees, see Day et al. (2009).

Many landscape trees are originally produced in-ground and later sold as bare-root "liners" to other producers who then plant them into large containers to grow to a finished plant (Harris, 2007). These liners are generally planted into a low-bulk-density, soilless substrate and, particularly if they are tall, structural roots are often buried deeper than necessary to minimize windthrow before new root growth firmly anchors the tree. Containergrown liners may also be planted deeply to minimize windthrow and to maximize stability during transport from potting areas to growing beds. Such deep planting of liners results in "finished" container plants with deep structural roots. Research reports on the consequences of the deep planting of liners are few. Fare (2006) reported that planting depth affected growth in the nursery of only one of five species tested. In Fare's study, roots had completely filled the container, creating a solid root ball with structural roots buried. The post-transplant consequence of buried structural roots within the container root ball of these or other trees is unknown. Gilman and Harchick (2008) reported that deep planting of cutting-grown live oak (Quercus virginiana 'SDLN' Cathedral $\mathrm{Oak}^{\circledR}$ ) resulted in additional adventitious roots and circling roots above the original buried main structural roots In an additional test of container production protocol, Gilman et al. (2010a) tested the effect of different planting depths when shifting three cutting-grown tree cultivars to larger containers on root system quality. Planting deep decreased top growth of two of the three cultivars. Although treatment effects were deemed statistically significant, the differences were considered to be inconsequential for commercial application. In addition, root system quality (i.e., severity of defects) was determined to be considerably worse on deepplanted trees. These defects were not visible because they were buried, prompting the authors to recommend washing substrate from the surface of root balls to inspect for and to treat root-system defects. In one recent report that tested the consequences of growing plants too deep in containers before transplanting to the landscape, Bryan et al. (2010) found that planting Ulmus parviflora Jacq. (Chinese Elm) with root collars buried $5 \mathrm{~cm}$ below original 
container surface, transplanting to larger containers with original root collar now $10 \mathrm{~cm}$ below surface, and then transplanting into a field soil for 1 year with original root collars now $15 \mathrm{~cm}$ below the surface reduced height but not trunk diameter compared with those trees with root collars always at grade.

The International Society of Arboriculture (ISA, 2005) recommends removing excess substrate on deep-grown container trees at transplant so as to expose the root flare (= transition zone between trunks and main structural roots). This practice is also recommended in Cooperative Extension bulletins produced by several state universities, including Kansas State University (Bomburger, 2008), Utah State University (Shao and Kuhns, 2010), and the University of Wisconsin (Bayer, 2004).

The consequences of following these recommendations to remove excess substrate and roots above root flares when transplanting container-grown trees to field soil (i.e., remediation) have not been reported. The objectives of our study therefore were to test the effects of planting depth of containergrown liners of pin oak and littleleaf linden on 1) growth during production in $0.05-\mathrm{m}^{3}$ (50-L; \#15) nursery containers and on 2) growth and development of root defects for three growing seasons after transplanting to field soil with and without remediation.

\section{Materials and Methods}

Littleleaf linden and pin oak trees, produced in $0.01-\mathrm{m}^{3}$ containers (11.4-L; \#3; $28 \mathrm{~cm}$ top diameter; $24 \mathrm{~cm}$ tall), were obtained from Lancaster Farms (Suffolk, VA) and repotted into $0.05-\mathrm{m}^{3}(50-\mathrm{L}$; \#15; $44 \mathrm{~cm}$ top diameter; $38.5 \mathrm{~cm}$ tall) containers with non-amended, semicomposted pine bark in June 2005. Approximately $5 \mathrm{~cm}$ of a dense mat of a combination of roots and substrate was removed from the bottom of each tree with a hand saw before transplanting. Seventyfive trees of each species were potted as follows: 15 potted with the root flare just exposed at the substrate surface; 30 with root flares $10 \mathrm{~cm}$ below the substrate surface; and 30 with root flares $20 \mathrm{~cm}$ below the substrate surface. Fifteen trees from each deeplyplanted group $(10 \mathrm{~cm}$ and $20 \mathrm{~cm}$ below the substrate surface) were randomly selected at this time for future remediation at transplanting to field soil (see subsequently). Each tree was fertilized with $100 \mathrm{~g} 15 \mathrm{~N}-3.9 \mathrm{P}-10 \mathrm{~K}$ (Osmocote Plus 15-9-12, 8-9 month Northern Formula; Scott's Company, Marysville, $\mathrm{OH}$ ) at planting and again the next March. Trees were grown for 17 months in a pot-in-pot system with socket pots $1.2 \mathrm{~m}$ apart in single rows aligned $1.5 \mathrm{~m}$ apart at the Urban Horticulture Center near the Virginia Tech campus in Blacksburg, VA. Species were grown in separate areas during container production and after transplant into field soil. Trunk diameter $30 \mathrm{~cm}$ above the substrate was initially measured on all trees at potting in June 2005 and then each year in midfall through- out the experiment. The location for trunk diameter measurement was marked with paint to ensure consistent measurements.

In late Nov. 2006, trees were transplanted $2 \mathrm{~m}$ apart into a single nursery row of Groseclose silt loam soil (clayey, mixed, mesic Typic Hapludults) with a pH of 6.2 at the Urban Horticulture Center. Planting holes were dug with a 61-cm tractor-mounted auger and randomly assigned treatments as follows: 1) trees grown and transplanted with root flares exposed (at grade); 2) trees grown with root flares $10 \mathrm{~cm}$ below grade, all roots and substrate above root flare removed and then planted with root flares exposed $(10 \mathrm{~cm}$ remediated); 3) trees grown with root flares $10 \mathrm{~cm}$ below grade and transplanted as such (10 cm deep); 4) trees grown with root flares $20 \mathrm{~cm}$ below grade, all roots and substrate above root flare removed and then planted with root flares exposed $(20 \mathrm{~cm}$ remediated); and 5) trees grown with root flares $20 \mathrm{~cm}$ below grade and transplanted as such $(20 \mathrm{~cm}$ deep). Roots and substrate on remediated trees were removed using a hand saw. Any adventitious roots on trunks above root flares on remediated trees were removed with hand pruners. Trees were hand-watered to apparent full field capacity immediately after transplanting and not irrigated again until 2007.
Trees were sporadically irrigated in 2007 and 2008 with a microemitter system $\left(30 \mathrm{~L} \cdot \mathrm{h}^{-1}\right)$ with one emitter per tree during dry periods. No irrigation was applied in 2009. After transplant, each tree was fertilized annually in early spring with $1.4 \mathrm{~kg} \mathrm{~N} /$ tree with $10 \mathrm{~N}-4.3 \mathrm{P}-8.3 \mathrm{~K}$ fertilizer (10-10-10; Weaver Fertilizer Co., Inc., Winston-Salem, NC) broadcast evenly over $1 \mathrm{~m}^{2}$ of ground area centered on the trunk of each tree. Tree rows were maintained with 7-cm-deep shredded hardwood bark mulch for the duration of the experiment.

Trunk diameter was recorded at planting and each fall thereafter until the experiment was ended in the fall of 2009 (= two growing seasons in containers + three post-transplant growing seasons) and converted to crosssectional area. Presence of vigorous shoots arising from soil near trunks or below first branch on trunks (suckers) was recorded in November of 2008 and coded as present or absent for each tree. In late Summer 2009, root collar excavation down to the original root flares was performed with an air excavation tool (Supersonic Air Knife Inc., Allison Park, PA) on five randomly selected trees of each treatment per species. Digital pictures of root system conditions were taken and qualitative observations of the presence and severity of trunk-girdling roots, severity of root

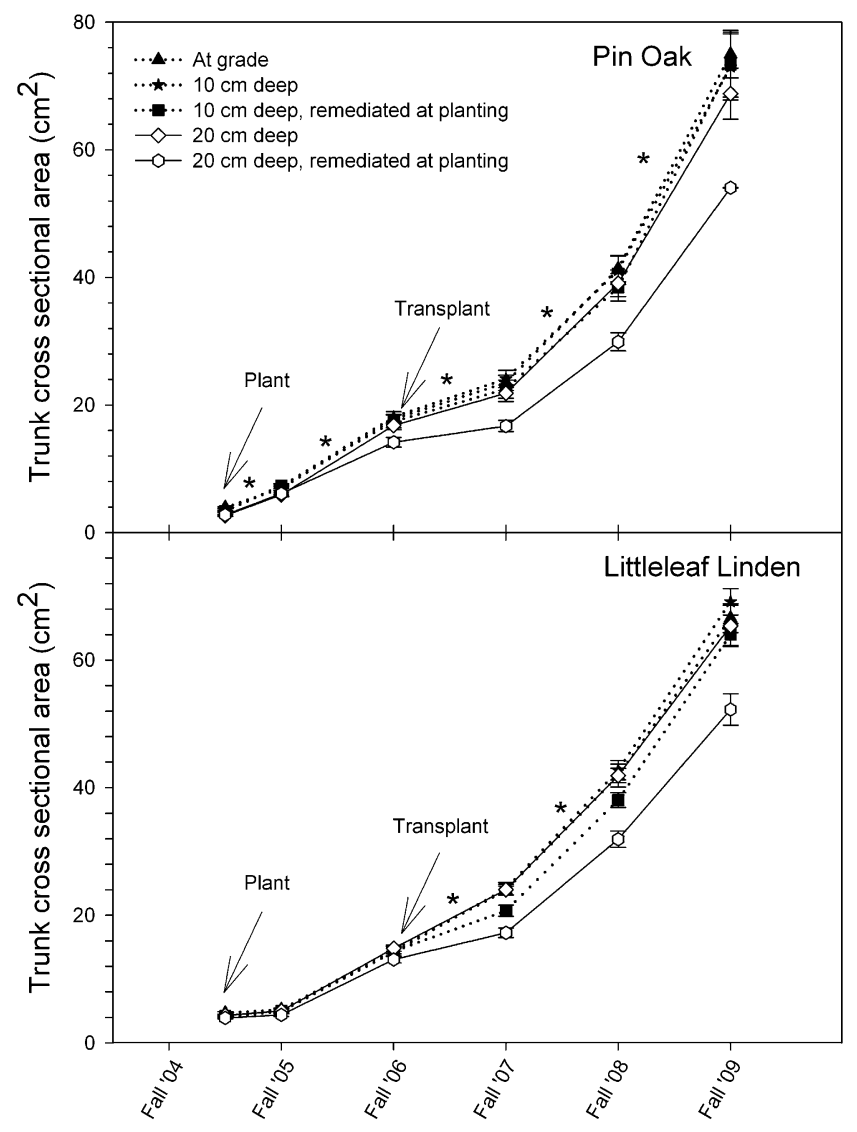

Fig. 1. Trunk cross-sectional area of Tilia cordata Mill. (littleleaf linden) and Quercus palustris Münchh. (pin oak) trees planted in 50-L nursery production containers with root flares at the substrate level (at grade), $10 \mathrm{~cm}$ below grade, or $20 \mathrm{~cm}$ below grade. Trees were grown for two growing seasons and then transplanted and grown for 3 years with container substrate surface even with soil surface or with roots and substrate removed so that original root flares were even with soil surface (remediated). $n=15$. Asterisks denote evidence of a treatment effect. See Table 1 for statistics. 
deformation, and the presence of adventitious roots were recorded.

The experimental design was completely randomized with 15 replications of five treatments for each species. Pin oak and littleleaf linden data were analyzed separately. Yearly growth data were analyzed with multivariate repeated-measures analysis of variance within the GLM procedure of SAS (Version 9.2; SAS Institute, Cary, NC). Univariate analysis of final tree size was performed using the GLM procedure of SAS, and trees not planted deep during container production (i.e., controls) were compared with other treatments. Presence of suckers was analyzed using the GENMOD procedure of SAS using the logit link. Treatment differences for yearly growth, final size, and sucker presence were determined by a priori single-degree-of-freedom contrasts.

\section{Results and Discussion}

Pin oak. Planting deep in containers reduced trunk cross-sectional area growth slightly during production (Fig. 1; Table 1). This was evident for the 10-cm-deep trees in production Season 1 and for the 20-cm-deep trees in production Season 2. This result was likely attributable to the dynamics of container water relations, but the exact reason that $20-\mathrm{cm}$-deep trees were unaffected along with $10-\mathrm{cm}$-deep trees during production Season 1 could not be determined. After transplanting to the well-drained field soil, deep planting or remediation of the $10-\mathrm{cm}$-deep trees did not affect growth. However, remediation of the 20-cm-deep trees reduced growth rate considerably (Fig. 1; Table 1). At the end of the experiment, remediation of the 20-cm-deep trees reduced growth by $28 \%(P<0.001)$ compared with trees maintained at grade during production and transplanting. No other treatments reduced final tree size compared with trees originally planted at grade in production containers. Compared with trees not grown deep in containers, $P$ values were $0.73,0.27$, and 0.34 for $10-\mathrm{cm}$ deep, 20-cm-deep, and 10-cm-deep-remediated trees, respectively. Root balls of all trees of both species that were originally planted deep filled the container during container production, so remediating the 20 -cm-deep tree removed slightly more than half of the root ball (Fig. 2A). It is not too surprising, therefore, that there was a concomitant reduction in growth.

Exposing root flares at transplanting (i.e., remediation) is thought to be a safeguard against future girdling roots. During remediation of deep-planted pin oaks, it was obvious that adventitious roots were abundant above the original root flare (Fig. 2A), and it is likely that they were becoming the major structural roots as we later observed when we excavated a subsample of non-remediated trees 3 years later (Fig. 2B). Although root deformities that appeared to be related to container production were evident for all treatments, the original roots that were circling around the container wall (deflected roots) did not

Table 1. $P$ values from a priori contrasts for trunk cross-sectional area of Quercus palustris Münchh. (pin oak) and Tilia cordata Mill. (littleleaf linden) trees grown for two growing seasons in 50-L containers before transplanting into field soil for three growing seasons with root flares at grade, $10 \mathrm{~cm}$ deep, 10 $\mathrm{cm}$ deep but remediated so root flares were at grade when transplanted, $20 \mathrm{~cm}$ deep, and $20 \mathrm{~cm}$ deep but remediated so root flares were at grade when transplanted $(\mathrm{n}=15)$.

\begin{tabular}{|c|c|c|c|c|c|}
\hline & \multicolumn{5}{|c|}{$\mathrm{P}>\mathrm{F}$} \\
\hline & $\begin{array}{c}\text { Container }^{z} \\
\text { Season } 1\end{array}$ & $\begin{array}{l}\text { Container } \\
\text { Season } 2\end{array}$ & $\begin{array}{c}\text { Field } \\
\text { Season } 1\end{array}$ & $\begin{array}{c}\text { Field } \\
\text { Season } 2\end{array}$ & $\begin{array}{c}\text { Field } \\
\text { Season } 3\end{array}$ \\
\hline \multicolumn{6}{|l|}{ Pin oak } \\
\hline At grade versus $10 \mathrm{~cm}$ deep $^{y}$ & 0.007 & 0.556 & 0.839 & 0.635 & 0.581 \\
\hline At grade versus $20 \mathrm{~cm}$ deep & 0.323 & 0.077 & 0.306 & 0.920 & 0.211 \\
\hline $10 \mathrm{~cm}$ deep versus $10 \mathrm{~cm}$ deep, remediated & NA & NA & 0.230 & 0.802 & 0.840 \\
\hline $20 \mathrm{~cm}$ deep versus $20 \mathrm{~cm}$ deep, remediated & NA & NA & 0.050 & 0.005 & 0.078 \\
\hline $10 \mathrm{~cm}$ deep versus $20 \mathrm{~cm}$ deep & NA & NA & 0.220 & 0.560 & 0.487 \\
\hline \multicolumn{6}{|l|}{ Littleleaf Linden } \\
\hline At grade versus $10 \mathrm{~cm}$ deep & 0.121 & 0.973 & 0.607 & 0.594 & 0.358 \\
\hline At grade versus $20 \mathrm{~cm}$ deep & 0.811 & 0.934 & 0.829 & 0.928 & 0.543 \\
\hline $10 \mathrm{~cm}$ deep versus $10 \mathrm{~cm}$ deep, remediated & $\mathrm{NA}^{\mathrm{x}}$ & NA & 0.001 & 0.272 & 0.818 \\
\hline $20 \mathrm{~cm}$ deep versus $20 \mathrm{~cm}$ deep, remediated & NA & NA & 0.001 & 0.005 & 0.116 \\
\hline $10 \mathrm{~cm}$ deep versus $20 \mathrm{~cm}$ deep & NA & NA & 0.466 & 0.534 & 0.142 \\
\hline
\end{tabular}

${ }^{\mathrm{z}}$ Container substrate $=100 \%$ milled pine bark.

${ }^{\mathrm{y}}$ Trees targeted for remediation pooled with those not targeted while in containers.

${ }^{\mathrm{x}} \mathrm{NA}=$ not applicable.

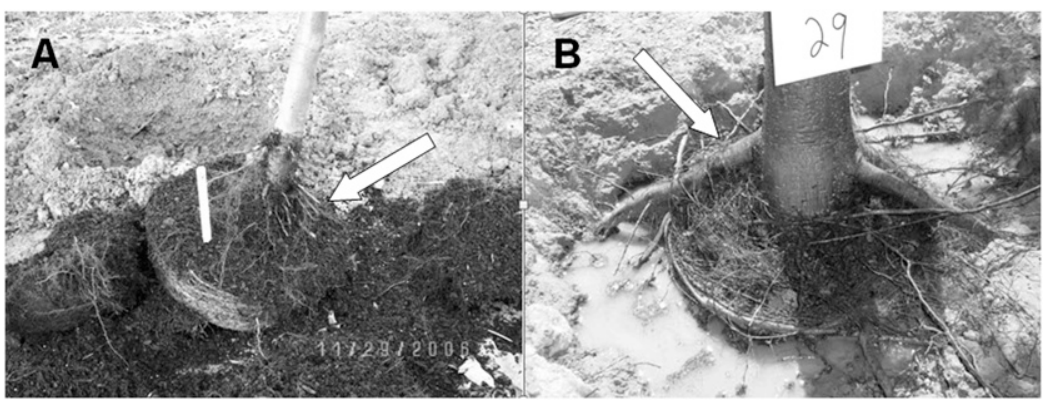

Fig. 2. Quercus palustris Münchh. (pin oak). (A) Tree originally grown in a nursery container with the root flare $20 \mathrm{~cm}$ below the substrate surface but remediated to bring the original root flare even with the landscape soil surface. The arrow points to adventitious roots formed along the trunk during container production. The white bar is a treatment tag. (B) Tree originally grown in a nursery container with the root flare $20 \mathrm{~cm}$ below the substrate surface and grown non-remediated for 3 years after transplanting to landscape soil. The arrow points to an adventitious root that appears to be in the process of becoming a main structural root.

generally appear to be rapidly growing 3 years after transplanting compared with adventitious roots that were never deflected. This was also noted on container-grown red maple (Gilman and Kane, 1990). In Gilman and Kane's study, adventitious roots were formed after transplanting and not during production so adventitious roots were not deflected by container sidewalls. Pin oak in our study formed adventitious roots during container production (Fig. 2A) and also after transplanting as is evident from the nondeflected roots in Figure 2B. Even if planted deep during container production, trees that readily produce adventitious roots like pin oak probably do not need to be remediated when planting to most landscape sites because adventitious roots formed after transplanting will likely establish a new system of structural roots near the soil surface. In other words, the new adventitious root system would likely replace the original deflected roots as the major root system of the tree, reducing the potential for ill effects from the circling roots. Nonetheless, trees should spend as little time in the production container as possible because adventitious roots forming at this time quickly become deflected by container sidewalls, similar to non-adventitious roots. Adventitious root formation as well as growth response to deep planting may be affected by site-specific soil conditions (e.g., drainage, oxygen content, bulk density) in some situations. In addition, adventitious roots may form only when the trees are very young. For example, Gilman and Harchick (2008) found that cuttingpropagated Quercus virginiana 'SDLN' only formed adventitious roots on buried stems when in \#3 containers and not after shifting up to larger containers. Although circling roots are generally considered a defect (even if they are not actively expanding), their effect on future health and stability of these trees can only be surmised. Girdling roots will likely impact general tree growth and health (Hudler and Beale, 1981) and trunk taper (Day and Harris, 2008), but a direct effect on tree stability has not been demonstrated (Kane, 2008). 


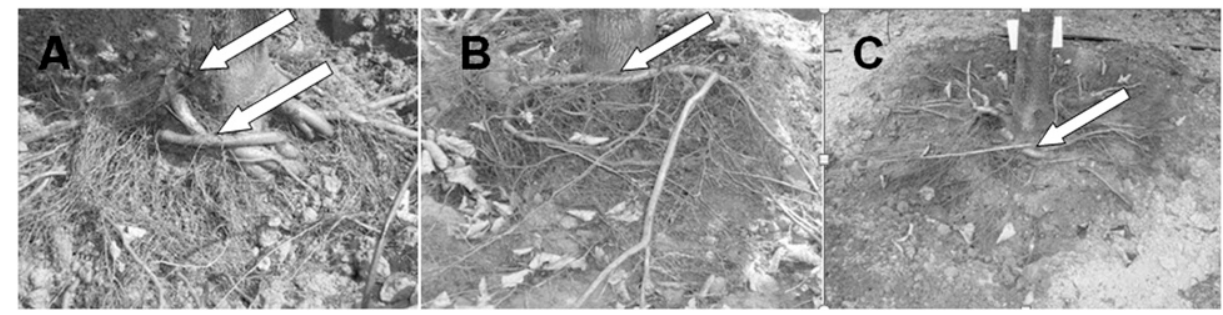

Fig. 3. Tilia cordata Mill. (littleleaf linden). (A) Tree originally grown with the original root flare at the container substrate surface and grown for 3 years after transplanting to a landscape soil. The top arrow points to a sucker stub after removal. The lower arrow points to vigorously growing original container roots that are still wrapped around the original root ball and cover structural roots. (B) Tree originally grown with the original root flare $10 \mathrm{~cm}$ below the container substrate surface and grown non-remediated for 3 years after transplanting to landscape soil. The arrow points to a potential trunk-girdling root. (C) Tree originally grown with the root flare $10 \mathrm{~cm}$ below the container substrate surface, remediated at transplant so the original root flare was even with the landscape soil surface, and grown for 3 years after transplanting. The arrow points to vigorously growing original container roots that are still wrapped around the original root ball and cover structural roots.

Littleleaf linden. Deep planting had little effect on growth during container production or when transplanted to the field (Fig. 1; Table 1). Remediating the 10 -cm-deep trees reduced growth the first year after transplanting to the simulated landscape and reduced growth was evident for remediated $20-\mathrm{cm}$ deep trees for 2 years after transplanting. Contrary to observations on pin oak, we saw no adventitious root formation on littleleaf linden before or after transplanting. Perhaps as a consequence, circling roots that were deflected during container production of littleleaf linden appeared to grow more vigorously than those of pin oak (Fig. 3A) and we observed more severe container conflicts (wrapping, twisted, convoluted, crossing, against trunks) in root systems of litteleaf linden than in pin oak. As such, remediation of deepplanted littleleaf linden would be critical to reducing future concern from trunk-girdling roots and may be desirable despite reduced post-remediation growth. We observed an abundance of potential trunk-girdling roots on both $10-\mathrm{cm}$-deep trees and 20-cm-deep trees (Fig. 3B). Although remediation removes most root conflicts with trunks, there would still be concern about future ill effects of circling roots on major structural roots (Fig. 3A, C). For littleleaf linden, remediation of the 20-cm-deep trees reduced growth by $20 \%$ compared with trees not grown deep in production containers $(P<0.001)$ after three growing seasons in the landscape (see Fig. 1). Similar to pin oak, no other treatments reduced growth compared with those originally container-grown at grade. Compared with trees not grown deep in containers, $P$ values were $0.45,0.73$, and 0.46 for 10-cm-deep, 20-cm-deep, and 10-cm-deep remediated trees, respectively.

The statistical test for treatment effects on the presence of suckers revealed that $20-\mathrm{cm}$ deep trees were least likely to have suckers, and remediating these trees increased sucker incidence (Table 2). Although suckers of littleleaf linden are considered very undesirable in a landscape setting and add to maintenance costs, the potential disadvantages of trunk-girdling roots on the 20 -cm-deep trees far outweigh any advantage that deep planting may give in preventing suckers.

Table 2. Numbers of individual Tilia cordata Mill. (littleleaf linden) trees with shoot sprouts originating below or near ground level or on lower trunks (suckers 2 years after transplanting). ${ }^{\mathrm{z}}$

\begin{tabular}{|c|c|c|c|}
\hline Treatment & $\begin{array}{l}\text { Trees with } \\
\text { suckers }\end{array}$ & $\begin{array}{l}\text { Trees without } \\
\text { suckers }\end{array}$ & $\begin{array}{l}\text { Percent with } \\
\text { suckers }\end{array}$ \\
\hline At grade & 10 & 5 & $67 \%$ \\
\hline $10 \mathrm{~cm}$ deep & 9 & 6 & $60 \%$ \\
\hline $10 \mathrm{~cm}$ deep remediated & 10 & 5 & $67 \%$ \\
\hline $20 \mathrm{~cm}$ deep & 4 & 11 & $27 \%$ \\
\hline $20 \mathrm{~cm}$ deep remediated & 10 & 5 & $67 \%$ \\
\hline \multicolumn{4}{|c|}{$\mathrm{P}>\chi^{2}$} \\
\hline At grade versus $10 \mathrm{~cm}$ deep & \multicolumn{3}{|c|}{0.705} \\
\hline At grade versus $20 \mathrm{~cm}$ deep & \multicolumn{3}{|c|}{0.026} \\
\hline $10 \mathrm{~cm}$ deep versus $10 \mathrm{~cm}$ deep, remediated & \multicolumn{3}{|c|}{0.705} \\
\hline $20 \mathrm{~cm}$ deep versus $20 \mathrm{~cm}$ deep, remediated & \multicolumn{3}{|c|}{0.026} \\
\hline $10 \mathrm{~cm}$ deep versus $20 \mathrm{~cm}$ deep & \multicolumn{3}{|c|}{0.063} \\
\hline
\end{tabular}

${ }^{2}$ Trees were originally planted into production containers at three depths. Root balls above original structural roots of deep trees were removed (remediated) at transplanting to field soil. $P$ values from a priori contrasts for the presence of suckers was assessed in Fall 2008, 2 years after transplanting. $n=15$.

\section{Conclusions}

Some tree species such as pin oak may form well-structured adventitious root systems near the soil surface after transplanting; and thus remediation at transplanting to expose original root flares may not be critical, especially because remediation may significantly reduce growth during the establishment period. Remediating 20-cm-deep pin oak trees compared with not remediating 20 -cm-deep trees reduced growth during the first three growing seasons in our study $(P<$ $0.050,0.005$, and 0.078 for transplant Seasons 1,2 , and 3 , respectively). In other species (e.g., littleleaf linden), no adventitious structural roots develop after transplant and structural roots formed early may serve for the life of the tree. Remediating these species so as to expose root flares and to remove circling roots at transplanting may be more critical to ensure future health and stability of the tree, and thus the resulting slower posttransplant growth is probably a justifiable expense. Our observations of littleleaf linden root system conditions 3 years after transplanting from 50-L containers lead us to suggest that root ball alteration at planting such as shaving or slicing outside edges (Gilman et al., 2010c) or the use of special rootpruning containers (Gilman et al., 2010b) should also be considered. Nursery practices that minimize deep planting of liners in con- tainers should be used as a general practice, regardless of species.

\section{Literature Cited}

Arnold, M., G.V. McDonald, and D.L. Bryan. 2005. Planting depth and mulch thickness affect establishment of green ash (Fraxinus pennsylvanica) and bougainvillea goldenraintree (Koelreutaria bipinnata). J. Arboric. 31:163-170.

Arnold, M.A., G.V. McDonald, D.L. Bryan, G.C. Denny, W.T. Watson, and L. Lombardini. 2007. Below-grade planting adversely affects survival and growth of tree species from five different families. Arboric. Urb. For. 33:64-69.

Bayer, D. 2004. Important things to remember when planting container and balled-and-burlapped trees. University of Wisconsin Cooperative Extension. 1 June 2010. <http://outgamie.uwex.edu/ hort/documents/treeplantingmethods.pdf $>$.

Bomburger, K. 2008. Handling and planting container-grown trees. Kansas State University Cooperative Extension. 1 June 2010. <http:// www.ksre.ksu.edu/library/forst $2 / \mathrm{mf1119}$.pdf>

Brady, N.C. and R.R. Weil. 2002. The nature and properties of soils. Prentice Hall, Upper Saddle River, NJ.

Bryan, D.L., M.A. Arnold, A. Volder, T.W. Watson, L. Lombardini, J.J. Sloan, L.A. Valdez-Aguilar, and A.D. Cartmill. 2010. Planting depth during container production and landscape establishment affects growth of Ulmus parvifolia. HortScience 45:54-60.

Day, S.D. and N.L. Bassuk. 1994. Effects of soil compaction and amelioration treatments on landscape trees. J. Arboric. 20:9-17. 
Day, S.D., N.L. Bassuk, and H. van Es. 1995. Effects of four compaction remediation methods for landscape trees on soil aeration, mechanical impedance and tree establishment. J. Environ. Hort. 13:64-71.

Day, S.D. and J.R. Harris. 2008. Growth, survival, and root system morphology of deeply planted Coryluys colurna seven years after transplanting and the effects of root collar excavation. Urb. For. Green. 7:119-128.

Day, S.D., J.R. Seiler, R. Kreh, and D.W. Smith. 2001. Overlaying compacted or uncompacted construction fill has no negative impact on white oak and sweetgum growth and physiology. Can. J. For. Res. 31:100-109.

Day, S.D., G. Watson, P.E. Wiseman, and J.R. Harris. 2009. Causes and consequences of deep structural roots in urban trees: From nursery production to landscape establishment. Arboric. Urb. For. 25:182-189.

Fare, D.C. 2006. Should pottiing depth be a concern with container crown trees? p. 25-28. In: Watson, G. (ed.). Proc. of Trees and Planting: Getting it Right; 10 Nov. 2005. The Morton Arboretum, Lisle, IL. 2 June 2010. < http://actrees.org/files/ Research/mortonarb_getting_roots_right.pdf $>$.

Fonteno, W.C. 1996. Growing media: Types and physical/chemical properties, p. 93-122. In: Reed,
D.W. (ed.). Water, media, and nutrition for greenhouse crops. Ball Publishing, Batavia, IL.

Gilman, E.F. and J. Grabosky. 2004. Mulch and planting depth affect live oak (Quercus virginia Mill.) establishment. J. Arboric. 30:311-317.

Gilman, E.F. and C. Harchick. 2008. Planting depth in containers affects root form and tree quality. J. Environ. Hort. 26:129-134.

Gilman, E.F., C. Harchick, and M. Paz. 2010a. Planting depth affects root form of three shade tree cultivars in containers. Arboric. Urb. For. 36:132-139.

Gilman, E.F., M. Paz, and C. Harchick. 2010b. Effect of container type on root form and growth of red maple. J. Environ. Hort. 28:1-7.

Gilman, E.F., M. Paz, and C. Harchick. 2010c. Root ball shaving improves root systems on seven tree species in containers. J. Environ. Hort. 28:13-18.

Gilman, E.F. and M.E. Kane. 1990. Root growth of red maple following planting from containers. HortScience 25:527-528.

Harris, J.R. 2007. Transplanting large trees. CAB Reviews: Perspectives in agriculture, veterinary science. Nutrition and Natural Resources 2:1-7.

Hudler, G.W. and M.A. Beale. 1981. Anatomical features of girdling root injury. J. Arboric. 7: 29-32.
ISA. 2005. New tree planting. 1 June 2010. $<$ http:// www.treesaregood.org/treecare/tree_planting. asp $>$. p. 1-3.

Kane, B. 2008. Tree failure following a windstorm in Brewster, Massachusetts, USA. Urb. For. Green. 7:15-23.

MacDonald, J.D., L.R. Costello, J.M. Lichter, and D. Quickert. 2004. Fill soil effects on soil aeration and tree growth. J. Arboric. 30:19 27.

Shao, M. and M. Kuhns. 2010. Planting landscape trees. Utah State University Cooperative Extension. 1 June 2010. <http://extension.usu.edu/ forestry/Reading/Assets/PDFDocs?NR_FF/ NRFF017.pdf $>$.

Spomer, L.A. 1980. Container soil relations: Production, maintenance and transplanting. J. Arboric. 6:315-320.

Sutton, R.F. and R.W. Tinus. 1983. Root and root system terminology. For. Sci. Monograph 24 (supplement to number 4, 1 Dec. 1983).

Wells, C., K. Townsend, J. Caldwell, D. Ham, E.T. Smiley, and M. Sherwood. 2006. Effects of planting depth on landscape tree survival and girdling root formation. Arboric. Urb. For. 32: 305-311.

Yelenosky, G. 1963. Soil aeration and tree growth. Proc. Intl. Shade Tree Conf. 39:16-25. 